\title{
Enantioselective Friedel-Crafts Alkylations by Strained Chiral Silacycle
}

Friedel-Crafts

alkylation

silacycles

Lewis acids 